\title{
CO ZPƯSOBUJE RAKOVINU DĚLOŽNÍHO ČÍPKU A JAK SE JÍ BRÁNIT?
}

\author{
Karel Pešl \\ GlaxoSmithKline, s. r. o., Praha
}

Rakovina děložního čípku patří společně s rakovinou prsu, děložního těla a tlustého střeva $\mathrm{k}$ nejrozšířenějším ženským onemocněním. Představuje typ rakoviny, u kterého byla jasně prokázána př́má souvislost mezi virovou nákazou a následným onemocněním. Rakovina děložního čípku je v ČR každoročně diagnostikována u zhruba tisíce žen, téměř 400 z nich na tuto nemoc zemře (Dušek a kol., 2010). Jde o druhou nejčastěji se vyskytující rakovinu u žen. Přitom přednádorový stav se vyvíjí mnoho let a lze jej zachytit dříve, než dospěje do stadia rakoviny děložního čípku.

\section{Co způsobuje rakovinu děložního čípku?}

Virus, který se za onemocněním téměř ve 100 procentech skrývá, se nazývá Human papillomavirus (HPV). Jedná se o velice běžný virus. Existuje více než 100 typů HPV a většina $z$ nich je neškodná. Pohlavním stykem se šírí okolo 40 typů (de Villiers et al., 2004). Mưžeme je rozdělit na dvě skupiny podle rizikovosti: na nízce rizikové a vysoce rizikové. Méně rizikové typy vyvolávají např. genitální bradavice, ty rizikové však zpơsobují změny buněk na povrchu děložního čípku, z nichž se může vyvinout rakovina.

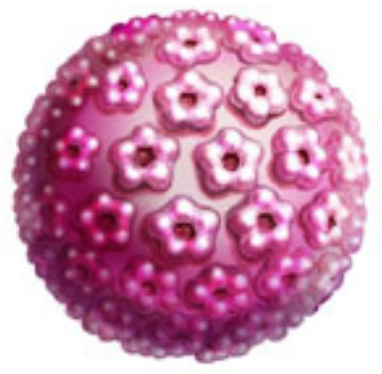

Obr. $1 \mathrm{HPV}$ virus
Mezi vysoce rizikové typy patří zejména HPV 16 a 18, které jsou zodpovědné za více než $70 \%$ př́ípadů rakoviny děložního čípku na celém světě, a dále typy $31,45,35,51$ a 52 (Paavonen, 2009; Souhrn údajů o pŕípravku Cervarix, 2010). HPV infekce probíhá bez příznaků a změny na děložním čípku způsobené HPV virem (obr. 1) odhalí až gynekologické vyšetření.

\section{Jak se HPV infekce přenáší?}

HPV viry se obvykle přenášejí sexuálním kontaktem. Nemusí to být jen sexuálním stykem, ale také dotykem s kůží nakaženého partnera v genitální oblasti. Proto kondom, který je velice účinnou ochranou před jinými sexuálně přenosnými nemocemi, zde není dostatečně účinným řešením. Nejde jen o to, kolik sexuálních partnerů žena za svůj život má, ale záleží také na sexuálním chování obou partnerů. S infekcí HPV se setká během života až 80 \% žen, $u$ většiny $z$ nich však infekce samovolně odezní. U některých žen ale přetrvává, a právě ony mají zvýšené riziko vzniku rakoviny děložního čípku. Navíc $\mathrm{v}$ průběhu života ženy může docházet k opakovaným infekcím.

\section{Co je rakovina děložního čípku?}

Děložní hrdlo se nachází na konci pochvy u vstupu do dělohy (obr. 2). Vnější část hrdla (čípek, latinsky cervix) vypadá jako hlavička hř́bku, který má uprostřed malý otvor. Jestliže dochází na povrchu čípku k nekontrolovanému množení buněk změněných infekcí HPV, mluvíme o rakovině. $K$ jejímu vzniku nedochází náhle: celý proces od počátečních stadií až po vznik rakoviny trvá léta.

Submitted: 2011-03-03 - Accepted: 2011-03-16 - Published online: 2011-03-28

KONTAKT: vol. 13, no. 1, pp 104-106 • ISSN 1212-4117 (Print) • ISSN 1804-7122 (Online) 


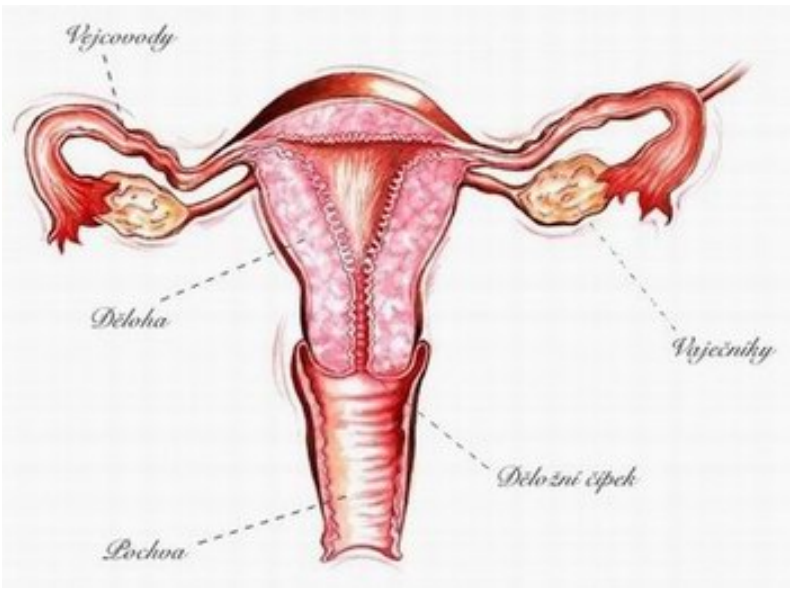

Obr. 2 Průřez děložním hrdlem

Jaké jsou možnosti vyšetření?

Změněné buňky lze již $\mathrm{v}$ počátečním stadiu zachytit pomocí cytologického stěru z děložního čípku, který bezbolestně provede gynekolog při pravidelné každoroční prohlídce. Stěr se pak odesílá do cytologické laboratoře, kde se zjišt'uje, zda vzorek obsahuje již změněné buňky. Pokud byly ve stěru nalezeny, jedná se o tzv. abnormální cytologický nález. Zdaleka to ovšem nemusí znamenat, že máte rakovinu. Důležité ovšem je všechny pacientky s abnormálním nálezem pečlivě sledovat, aby se předešlo vzniku rakoviny. To může znamenat opakovaný stěr či detailnější vyšetření děložního čípku pomocí speciálního mikroskopu, tzv. kolposkopu. Nutno podotknout, že i stěr z děložního čípku není stoprocentně spolehlivý a jeho výsledek může být falešně negativní.

Zjistí-li lékař kolposkopií jakékoliv změny buněk na čípku, odebere tzv. biopsií malou část tkáně a odešle ji na další laboratorní vyšetření. $\mathrm{Na}$ základě jejich výsledků lékař stanoví optimální léčbu.

\section{Jaké jsou možnosti léčby?}

Cílem léčby je odstranit změněné buňky tak, aby nemohlo dojít $\mathrm{k}$ jejich rakovinnému bujení. Výkony se provádějí nejčastěji ambulantně nebo během krátkého pobytu $\mathrm{v}$ nemocnici.

Pro léčbu se používá několik metod:

- kryoterapie - odstranění změněné tkáně zmrazením;
- laserová léčba - odstranění změněné tkáně laserem;

- konizace - tkáň ve tvaru konusu se vyřízne pomocí jehly nebo skalpelu;

- elektrická klička - dnes nejčastěji používaná metoda $\mathrm{k}$ odstranění tkáně pomocí drátěné kličky, která pro řez využívá energie nepoškozující termicky ani čípek, ani odstraněnou tkáň.

Tyto výkony však nemusí znamenat definitivní řešení, někdy je potřeba je opakovat nebo zvolit radikálnější operační řešení.

\section{Dá se rakovině děložního čípku předejít?}

Každý z nás je zcela odpovědný za své zdraví. Účinná prevence rakoviny děložního čípku spočivá především $\mathbf{v}$ pravidelných gynekologických prohlídkách. Preventivní stěr děložního čípku jednou ročně navíc pojišt'ovna hradí, takže zde opravdu není prostor na výmluvy.

Ani ta nejpravidelnější prohlídka ale nezabrání vzniku infekce - díky ní lze „pouze“ zahájit včas vhodnou léčbu proti již vzniklému onemocnění. Proto je nevhodnější prevencí před onemocněním rakovinou děložního čípku kombinace pravidelných gynekologických prohlídek a očkování, které chrání proti nejvíce agresivním typům HPV.

Ideálním okamžikem k očkování je období ještě před zahájením pohlavního života, ale prospěch z očkování mají i ženy, které již po- 
hlavním životem žijí. Očkování sestává ze tři injekcí aplikovaných do deltového svalu. Druhá dávka se podává měsíc po první a třetí pět měsíců po druhé dávce (Souhrn údajů o prrípravku Cervarix, 2010). O prŕípadné nutnosti možného přeočkování rozhodnou až dlouhodobá sledování.
Př́pravek je pouze na lékařský předpis a není hrazen z prostředků veřejného zdravotního pojištění. Před použitím si pečlivě přečtěte př́balový leták.

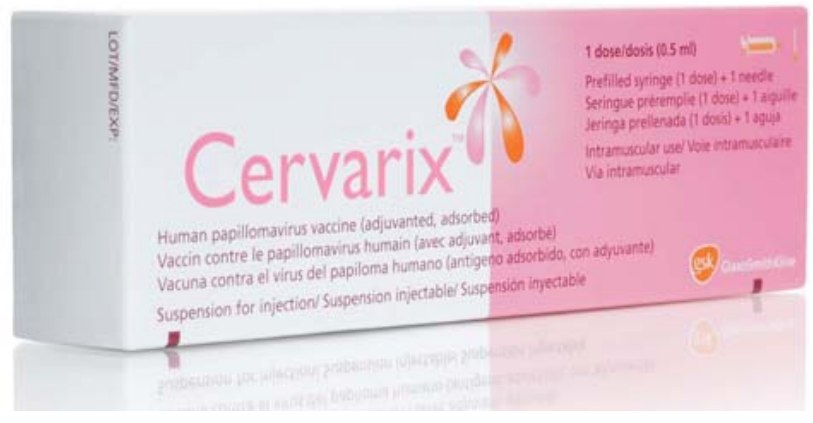

Obr. 3 Přípravek Cervarix

Až $80 \%$ žen se setká ve svém životě s HPV infekcí a pouze v 50-80\% prrípadů infekce spontánně odezní. Zbytek případů přechází do tzv. perzistentní infekce, která je prvním předpokladem vzniku přednádorových změn. Toto riziko se s věkem zvyšuje. Každá žena by měla o tomto riziku uvažovat a informovat se o možnostech prevence u svého gynekologa.

\section{LITERATURA}

de VILLIERS, E. M. et al.: Minireview: Classification of papillomaviruses. In: Virology, 2004, no 324, p. 17-27.

DUŠEK L. a kol.: Czech cancer care in numbers 20082009. Praha: Grada Publishing, 2010, s. 496.
PAAVONEN, J. et al.: Efficacy of human papillomavirus (HPV)-16/18 AS04-adjuvanted vaccine against cervical infection and precancer caused by oncogenic HPV types (PATRICIA): final analysis of a double-blind, randomised study in young women. The Lancet, 2009, vol. 374, no 9686 , p. 301-314.

Souhrn údajů o přípravku Cervarix. [online]. 2010 [cit. 2011-03-15]. Dostupné z:

http://www.cervikalnikarcinom.cz/Cervarix.aspx 